https://helda.helsinki.fi

\title{
On the socio-technical practices of the European Union territory
}

\author{
Luukkonen, Juho
}

2016-07-07

Luukkonen , J \& Moisio , S 2016 , ' On the socio-technical practices of the European Union territory ' , Environment and Planning A , vol. 48 , no. 8 , pp. 1452-1472 . https://doi.org/10.1177/0308518X16641413

http://hdl.handle.net/10138/174045

https://doi.org/10.1177/0308518X16641413

acceptedVersion

Downloaded from Helda, University of Helsinki institutional repository.

This is an electronic reprint of the original article.

This reprint may differ from the original in pagination and typographic detail.

Please cite the original version. 


\section{On the socio-technical practices of the European Union territory}

Juho Luukkonen and Sami Moisio

In press in Environment and Planning A. 2016. doi:10.1177/0308518X16641413

We examine the constitution of the EU territory in socio-technical practices. We argue that calculative practices are central in the constitution of the EU territory but that these practices need to be understood as being situated within the broader 'teleological structures' of European integration. This paper scrutinizes the ESPON programme as one of the activity spaces whereby the calculative practices of the 'European knowledge-based economy', a term which arose in the 1990s, are constitutive of the contemporary making of the EU territory. We thus highlight the practices of surveying, mapping and modelling as central components in the constitution of the EU as a political object.

Key words: activity space, EU territory, knowledge-based economy, socio-technical practices, teleological structure

\section{Introduction}

In this article, we examine the EU-orchestrated socio-technical practices of the EU territory. We highlight the role of socio-technical practices of surveying, mapping and modelling as mediums through which the EU territory is produced, as well as the centrality of these practices for the very existence of the EU territory as a political object. We thus share the view that "EUropean space making is explicitly about the political production of 'European spaces', rather than simply the deployment of 'European' policies in already existing political space" (Bialasiewicz et al, 2013, page 60). 
The idea of the EU as a territory underscores the multiple ways in which the formation of the EU as a 'coherent' political object takes place within the relational and networked spaces of Europeanization (cf, Bachmann, 2015a; Bialasiewicz et al, 2005; Jensen and Richardson, 2004; Luukkonen 2011; Moisio et al, 2013). In such a view, the political geography of the EU can be understood as a stratum of differentially scaled and overlapping spaces, networks and places of governance (e.g. Clark and Jones, 2008; Sidaway, 2006).

The article discusses two aspects which, we believe, have not been adequately treated in the studies which focus on the spatial constitution of the EU. First, the explicitly 'bordering' policies of the EU, such as the Schengen Agreement or Frontex (the European Agency for the Management of Operational Cooperation at the External Borders of the Member States of the European Union), are not the only policies whereby the territorializing of the EU takes place. For instance, the policies of so-called European spatial planning are not necessarily directly linked to the EU's external or internal borders but nonetheless play a significant role in shaping, managing and regulating the EU territory. This motivates one to examine the seemingly neutral and routinized ways through which the EU territory is practiced as a political object in different EU policies (see also Jensen and Richardson, 2004; Kuus, 2014; Walters and Haahr, 2005).

Second, we bring to the fore the territorial aspects of the so-called European knowledge-based economy. By knowledge-based economy we do not refer to a self-contained sphere of economic activities but rather to a political artifact that is made out of processes which involve both discursive and material components (cf, Mitchell, 2002, page 82). Despite the fact that the 'knowledge-based economy' has been one of the central political strategies of the EU for nearly two decades, the territory effects (Painter, 2010) of such 'economy' have not been adequately examined. We highlight in particular that the 'European knowledge-based economy' can be understood as a teleological structure (Schatzki, 2010) which significantly conditions the calculative practices of the EU territory. 
To demonstrate the above-mentioned argument we scrutinize the so-called ESPON programme (European Observation Network, Territorial Development and Cohesion, formerly known as European Spatial Planning Observation Network). ESPON is an EU-funded research network which produces scientific information for the purposes of European spatial development policies. The first ESPON programme was launched in order to strengthen and provide the analytical base for the first European-wide spatial development strategy, called the European Spatial Development Perspective (ESDP) (Faludi 2010, page 146). From the beginning, the activities of the ESPON have been driven by the principle of the production of high-quality, just-in-time information on European spatial development, with the underlying goal of promoting a European-wide territorial perspective on policymaking.

While the financial volumes of the ESPON have been relatively modest, the growth of the programme budgets would imply that the need for "pan-European, comparable, systematic and reliable territorial evidence" (ESPON 2015, page 7) is still high on the Commission's agenda. Since its inception, the budgets of the programming periods have grown remarkably: for ESPON 2006 (2002-2006) the budget was 14.4 million euros, for ESPON 2013 (2007-2013) it rose to 45.4 million, whereas the current ESPON 2020 programme (2014-2016) has been budgeted approximately 48.6 million euros. Aside from its growing financial figures, the importance of the ESPON lies also in its capacity as a "learning machine" (Faludi, 2010, page 147; Moisio and Luukkonen, 2015) which bridges the gap between policymaking and academic research by bringing together hundreds of European policymakers, administrators, scientists and other experts.

Our analysis of the socio-technical practices of the EU territory is based on three distinctive yet interrelated sets of research materials. First, we examine the policy documents that have outlined the spatial dimensions of the EU's knowledge-based economy strategy from the early 1990s to present. We in particular interrogate how the hoped-for economic strategy has been articulated as a territorial strategy. Second, as a supplementary material, fifteen interviews with policy analysts and officers working at the European Commission's DG Regional and Urban Policy were conducted in Brussels in 2014-2015. The interviews 
focused explicitly on the calculative techniques of the EU's spatial policies. We do not treat the policy documents and interviews as a mere collection of sayings and statements but analyse these as part of the wider teleological structure of the European knowledge-based economy which orders - among various other material and immaterial entities - the socio-technical practices through which the EU territory is produced as a political object (cf. Schatzki 2002, page 20). The third set of research materials consists of the research project publications/materials of the ESPON 2013 programme. We study the ways how these projects engaged with the teleological structure of the European knowledge-based economy.

Our analysis of the ESPON as an activity space underlines that the 'European knowledge-based economy' is tied to surveys, models and mappings of the EU territory. We also argue that the knowledge production regarding the EU territory is both dictated and motivated by the chosen economic strategy - which has subsumed other EU policies under its priorities and strategic aims (Krzyżanowski and Wodak, 2011). In other words, the territory of the EU should not be comprehended as a distinctive set of policies but rather as a constituent and effect of the contemporary economic strategies.

The article proceeds as follows. Section two conceptualizes the EU territory from the practice theoretical perspective. Section three discusses the centrality of the discourses of the 'European knowledge-based economy' in contemporary European integration. Section four scrutinizes the ESPON research programme as one of the 'activity spaces' of the EU territory which enable and make meaningful the surveying, mapping and modelling of the EU as a singular political object. Section five interrogates the ways in which these calculations are predicated on particular teleological structures that see the future of the EU in terms of the 'knowledge-based economy'. In the concluding remarks, we put together our key arguments and make some suggestions about potential future research perspectives.

\section{Practicing the EU territory in 'activity spaces' and 'teleological structures'}


An orthodox understanding of territory treats territory as delimited, contiguous and coherent political space which is jurisdictionally delimited and internally coherent functional whole. This view on territory has been challenged by those who conceptualize territory as a social and cultural process. To illustrate, in his analysis of English administrative regions, Joe Painter (2010, page 1103) demonstrates how "the exercise of regional administrative power in the economic field results in the production of territorial understandings of economic practices and processes", of which one such understanding is the very idea of "the regional economy".

What is central in Painter's (2010) conceptualization is that in order to sustain the territory-effect the delimitation, contiguity and coherence of political space must be constantly reproduced through governmental technologies. This idea combines the idea of territory as a political technology for controlling space and populations (e.g. Elden, 2010) with the role of political agency in the production of territory as a particular type of policy object which is produced in networked social practices. The idea of territory as consisting of networked social practices is relevant in the context of the EU, which, due to its complex territorial configurations of authority (Sidaway, 2006), involves various formal and informal spaces of interaction (Bachmann, 2015b; see also Clark and Jones, 2008) whereby EU territory is negotiated and articulated.

We conceptualize the EU territory as a historically contingent bundle of various socio-technical practices, discourses and related materialities. To analyse the concrete socio-technical practices of the EU territory, we build in particular on two concepts which are discussed in Schatzki's (e.g. 1996; 2002; 2010; 2015) practice theoretical perspective: 'activity space' and 'teleological structure'. As regards the latter, particular practices can be discerned through the distinctive understandings, rules and teleological ends which organize the practice in question (Schatzki, 2010, page 73). The socio-technical practices that contribute to the constitution of 'the EU economy', for instance, are organized by certain shared understandings, norms and teleological ends which shape how the EU is imagined and acted upon as a political object. 
The basic idea behind the concept of the activity space is that practice-arrangement bundles contain what Schatzki (2010; 2015) calls “interwoven activity timespaces”. In other words, the socio-technical practices of knowledge production are inherently spatial phenomena in the sense that "social practices that make spaces themselves are and have spaces" (Schatzki, 2015, page 1). In our conceptualization, activity space does not refer to space as an objective category, i.e. an abstract realm or container in which human activities take place, but as constitutive dimension of human activities, i.e. something that is 'opened' or comes to be in human activities (Schatzki, 2010, page xi). ${ }^{1}$ The spatial component of the activity timespace involves "arrays of places and paths anchored at material entities", in which places refer to places to perform actions, and paths to avenues from one place to another (Schatzki, 2015, page 2). The places and paths do not, however, refer only to the physical locations and passages within and along which human activities take place but also implies their role as stage-settings in which particular human actions and material arrangements become meaningfully connected and in which both the actions and the (im-)material entities bear mutual relevance (e.g. Schatzki, 2010, pages 51-52). The spatiality of political life in this sense is produced; it is dependent on human actions and, of course, on the comprehension of what actions, material arrangements and places and paths belong together.

In political life, the activity spaces are basically the property of individuals. These spaces interweave when people participate in social practices, which, as indicated above, bear certain common, shared and orchestrated components. Consequently, the particular socio-technical practice of European integration can be regarded as forming a complex collective 'activity space' which rests upon common, shared and orchestrated places and paths, as well as upon the material arrangements and normative organizations (i.e. rules, norms, understandings, purposes etc.) that circumscribe the activities involved in that EU-orchestrated practice. Policy practices such as the running of an EU-funded regional development project in a given location or the collection of numerical data in the Eurostat (the statistical office of the European Union located in Luxembourg), for instance, are not merely activities taking place in a pre-existing EU territory. Rather, these practices engender the structured activity spaces of the EU territory. As a political object the EU territory is constituted in interactive activity spaces. These comprise socio-technical practices which tie 
together actors (e.g. research institutes, policy think tanks, individual debaters and scholars of various type), their expertise, techniques of knowledge production, as well as historically contingent teleological structures of European integration (cf, Bachmann, 2015b; see also Clark and Jones, 2008, for "spaces of Europeanization").

There are numerous activity spaces of the EU territory. In this paper we are interested in the ESPON programme, which analyses the qualities of the EU and its regions through surveying, spatial modelling and cartography. We highlight not only how effectuating the EU territory in the activity spaces requires inputs of expertise and labor (Brighenti, 2014; Kuus, 2014; Painter, 2010), but also how the recent calculative techniques of the EU territory - the peculiar 'quantification' of the EU - are situated within particular teleological structures. In order to situate our analysis of the contemporary making of the EU territory in ESPON, we discuss the 'European knowledge-based economy' as a teleological structure which has significantly conditioned the production of the EU territory within the ESPON research programme in the 2000s.

\title{
The European knowledge-based economy as a teleological structure
}

\begin{abstract}
"What is our biggest problem in Europe? I mean, this started with the Aho report: innovation is our biggest problem. We have a lot of research, we don't bring it to the market. How do you get competitive? Again, it's innovation, right? What is the problem in the southern periphery? They are not innovative enough, they don't have new products, new services. They don't have high added value production. They are not embedded in global value chains, in addition to being inefficient in many other ways. They have fantastic infrastructure ... but nothing happens there, economically." (EU official, 11
\end{abstract}

November 2014)

Since the 1990s in particular, the process of European integration has been fundamentally predicated on an idea of economic competition between Europe, Asia and the US. The formation of such discursive space of competition was later accompanied by concrete policies which were structured around the issue of 
competitiveness. More specifically, the whole debate on 'European economic competitiveness' vis-à-vis its rivals brought together three powerful political ideas, two of which were ultimately political geographical.

Firstly, the construction of the single market in the early 1990s was premised on a view that the European states were 'too small' to compete on the 'global sphere' in the age of purportedly new capitalist globalization. Secondly, the diminutive size of European states was coupled with another political idea related to the need to qualitatively reconstruct the entire economic structure at the scale of the EU. Since the 1990s the competitiveness problem has been articulated as a need to move away from the 'resource economy' towards the 'knowledge-economy' or even the 'information-society', whatever ways the 'knowledge-economy' or the 'information-society' were articulated (for different meanings, see Webster, 2006). Thirdly, from the 1990s onwards, the European debate on competitiveness was predicated on a view that European competitiveness problems had to do with the territorial organization of the EU (Moisio, 2011). We therefore claim that the formation of the EUropean competitiveness problem and the associated exercise of political power in the economic field since the 1990s has resulted in the production of territorial understandings of the economic practices of the EU as a particular regional economy or spatial economy (cf, Painter, 2010, page 1103).

The knowledge-based economy is an OECD-promoted idea (see Godin, 2006) and it has been a central component in the EU-orchestrated constitution of Europe as a distinctive economic and political entity during the past two decades (Moisio, 2015). In political terms, the concept refers to those advanced economies which are "directly based on the production, distribution and use of knowledge and information" (OECD, 1996, page 7). The idea of a knowledge-based economy derives from the notion that knowledge has become "the most fundamental resource" and, accordingly, learning "the most important process" in the modern economy (Lundvall, 1992, page 1). In our analysis, however, the knowledge-based economy does not refer to any actually existing 'European economic system' or occupational structure of the EU, or even to the role of intangible resources in the European economy. Rather, the knowledge-based economy is a ubiquitous political process: a combination of discourses and institutional as well as administrative 
mechanisms and structures of knowledge which render the social reality of the EU thinkable in a particular way.

The idea of turning the EU into a world-class knowledge economy was not an unavoidable, fated development path dictated by globalization but a selected and institutionally retained political choice. It is an envisioned 'economy' which is rationalized by the fear of Europe losing its position in global economic competition as well as by concerns related to the development of the EU's internal markets. Much of the emergence of the idea culminated in the launching of the so-called Lisbon Agenda at the EU Council Meeting in Lisbon in 2000. This summit was a significant milestone in a process which had started already in 1993 with the publication of the White Paper on Growth, Competitiveness, and Jobs issued by Jacques Delors with a view of alleviating the European unemployment crisis (Jones, 2005). The Lisbon meeting published a strategy which set for the EU the goal of "becom[ing] the most competitive and dynamic knowledge-based economy in the world capable of sustainable economic growth with more and better jobs and greater social cohesion" (European Council, 2000, page 5).

Since the Lisbon meeting, despite its poor success as regards the goals set in the strategy, this overall economic goal has been among the leading political agendas of the EU and has subsumed other EU policies under its priorities and strategic aims (Krzyżanowski and Wodak, 2011). Indeed, the Lisbon Agenda is predicated on an idea that the EU as the 'European society' could be developed through the knowledge economy. This is explicitly spelled out in the original presidency conclusions:

\footnotetext{
"The European Union is confronted with a quantum shift resulting from globalization and the challenges of a new knowledge-driven economy. These changes are affecting every aspect of people's lives and require a radical transformation of the European economy. The Union must shape these changes in a manner consistent with its values and concepts of society...." (European Council, 2000, page 5).
}

It could be said that apart from being the end goal of the economic restructuring of the EU, the knowledgebased economy has been, from the very beginning, a territorializing strategy for Europe. This strategy starts 
with the premises that the global has become an actually existing sphere of action and that the only way to succeed and survive the present conditions of constantly intensifying global competition is to get the knowledge-driven economic strategy realized at the level of 'European society' (e.g. European Communities, 2006). Accordingly, investments should focus on education, research and development activities, and innovation, for, as one interviewee stated:

"Because I think, if you look more globally now, that's where Europe should have a comparative advantage as a whole, as opposed to ... countries where labour costs are very low.” (EU official, 21 May 2015)

The Lisbon strategy - like many other EU policies related to economy - is often considered to be 'spatially blind' since it does not "distinguish between different parts of the EU" (EC, 2010a, page 179). However, the original strategy strongly promotes the idea of Europe as a singular space consisting of components, populations and substances which are tied together in networks, regions and places.

Explicit instructions for organizing the European knowledge economy spatially were enshrined already in the European Spatial Development Perspective document (ESDP) published by the Commission of European Communities in 1999 (CSD, 1999). The document identified the European competitiveness problem as partially a consequence of Europe's spatial disorder (cf, Faludi, 2010, page 111; Moisio, 2011, page 21) and presented a set of instructions which resonate explicitly with the later outlines of the Lisbon Agenda. These instructions concerned issues such as how to organize European space to make better use of the economic potential of all of the EU's regions and how to guarantee parity of access to infrastructure and knowledge in different parts of Europe (CSD, 1999, pages 20-30).

The alliance between the development of the European knowledge-based economies and Europe's spatial ordering has been further confirmed in the successor documents of the Lisbon strategy and the ESDP. The Territorial Agenda of the European Union was launched in 2007 as a response to “the 'non-spatial turn' in EU policy" (Dühr et al, 2010, page 217). The connections between the Territorial Agenda, the Lisbon strategy and the ESDP are obvious since it involved policy priorities such as the strengthening polycentric 
development and innovation through networking of cities, promoting regional clusters of competition and innovation in Europe, and strengthening of trans-European networks (EU Ministers..., 2007).

The Lisbon strategy was later replaced by the Europe 2020 strategy published in 2010 . The strategy sets three mutually supporting priorities for tackling the structural weaknesses of a Europe confronted with intensifying global challenges. The priorities of smart, sustainable and inclusive growth are set in order to develop "an economy based on knowledge and innovation", to promote "a more resource efficient, greener and more competitive economy" and to foster "a high-employment economy delivering economic, social and territorial cohesion" (EC, 2010b, page 10). These aims are formulated into seven 'flagship initiatives' which epitomize - even more strongly than the Lisbon strategy - the eagerness to make the EU the world's leading knowledge-based economy.

The priorities and goals of the launched strategy were later spatialized in a document called the Territorial Agenda of the European Union 2020. Adopted by the EU member states' ministers responsible for spatial planning and development in May 2011, this informal political document was meant to ensure that the territorial dimension is taken into account in the implementation of the Europe 2020 strategy (EU Ministers..., 2011, page 3). The document, with a subtitle of "towards an inclusive, smart and sustainable Europe of diverse regions", listed six territorial priorities for the development of the European Union. The basic spatial idea of the document is the creation of a functional and coherent whole which enables unimpeded mobility of resources and effective use of diverse territorial capitals (e.g. EU Ministers..., 2011, pages 6-8).

These political strategies are central expressive components in the constitution of the European knowledgebased economy. They articulate the setting - i.e. past global economic occurrences, present global economic situation and possible future scenarios - for the emergence of this particular 'economy' as a territorial whole. As these texts also describe what kind of global position Europe and its populations are in, how they ought to be, where they ought to end up, and what happens if the chosen goal remains unattained (e.g. 
European Communities, 2006, page 19), the documents of the European knowledge-based economy are subjectivating. $^{2}$

The centrality of the 'European knowledge-based economy' within those documents frames an explicit political project which is supposed to guide and condition the routine work of policymakers across the EU. Taken together, the documents disclose a particular discourse of economic growth as a teleological structure which orders thinking about and acting upon the EU territory as a political object.

\section{The socio-technical practices of the EU territory: ESPON as an activity space}

As noted earlier, as a political object the EU territory is a constellation of various practice-arrangement bundles. These bundles can be seen as activity spaces in which the EU territory becomes manifested. One of the spaces is the ESPON programme which produces scientific information for the purposes of European spatial development policies. The very rationale for establishing the ESPON programme in the early 2000s was essentially tied to the EU's political agendas and especially to the overarching challenges of Europe's economic stagnation and lack of competitiveness. The programme was launched in order to provide geographical information and evidence to support policymaking in Europe so that it could be conducted more efficiently and effectively with regard to the strengthening of Europe's economic and social development vis-à-vis its 'global rivals'. In general, the launching of the ESPON programme symptomizes the political desire for evidence-based policymaking and the overall fascination with knowledge as an economically and politically valuable asset (cf, Davoudi, 2006). In the following, we distinguish three central spatial dimensions of the ESPON programme.

First, the ESPON can be understood as a producer of spatial representations such as maps, diagrams, models and comparisons of Europe. The ESPON has produced dozens of research reports and policy proposals which are impregnated with visual representations. These visualizations are premised on hundreds of policy concepts and indicators which are tailored within the ESPON (Table 1). 
TABLE 1 somewhere here

The goals set for the ESPON programmes in general as well as for the forms of the provided data and information, and for the practices of knowledge production in particular, resonate with Timothy Mitchell's (2002) observations about the construction of an economy as a distinctive sphere of the social in late nineteenth-century Egypt. The visual representations and the construction of European-wide databases deployed in various ESPON projects epitomize the attempts to make European political and economic space into an object of knowledge by transforming the complexities of the 'real world' to abstractions on maps, graphs and statistical scoreboards. The seemingly objective representations of the ESPON programme are part of the wide-ranging realm of techniques which allow 'Europe' and the 'European economy' to be inscribed as political objects (cf, Miller and Rose, 2008). Their representational significance lies in their ability to turn the discursive realm of strategic policy documents into material conditions represented in harmonized data sheets, graphs and indices which, in turn, provide a basis for establishing standardized policy procedures and assessment tools for monitoring and governing the development of the economy (cf, Barry, 1993).

In ESPON, the production of harmonized data and the storage of the records in large databases play a significant material role in the constitution of the EU territory. They allow the "permanent registration" (DeLanda, 2006, page 73) of the performance of European regions and EU member states. Together with the abstract cartographic and infographic ${ }^{3}$ representations, they transform Europe into "a self-contained object whose 'problems' [can] be measured, analysed, and addressed by a form of knowledge that appears to stand outside the object and grasp it in its entirety" (Mitchell, 2002, page 100). The novelty of the ESPON in the history of European integration is precisely its concerted representational effort to produce European places, networks, flows, and spatial structures as calculable and comparable. The transformation of Europe from unknown supranational 'surface' into calculable and comparable 'EU-space' is arguably germane to the emerging understanding of the causal relationship between the EU's policy practices, policy 
recommendations and broader regional development trends. The programme is thus a response to the concerns, expressed by many of the interviewed officials, over the lack of appropriate ways for evaluating the performativity and resultativeness of the EU's regional policies.

Secondly, the ESPON programme can be understood as a network of places and institutions within which the activities of the programme are situated and through which funding is organized. The programme covers all the EU Member States and four non-member states. The ESPON is co-financed by the EU (European Regional Development Fund, Objective 3), i.e. EU28 states, and by Iceland, Lichtenstein, Norway and Switzerland. The programme is active in all ESPON member states and represents a spatially dispersed network of planning agencies, research institutions and "contact points", as well as individual scholars and policymakers operating within it (see Figure 1).

PLACE FIGURE 1 AROUND HERE (The network of research institutions and teams involved in the ESPON programme (source: ESPON 2014a, page 64).)

Thirdly, the ESPON programme constitutes an activity space within which the EU is constituted as a political object (cf, Bachmann 2015a, page 691). The ESPON brings together expertise of university scholars, research institutes and planning agencies, and the techniques they employ. The ESPON thus functions as a sort of epistemic community that makes the territory of the EU visible and amenable to analysis and regulation through informed scientific analysis. Moreover, scientific and other interaction within the ESPON are inescapably conditioned by teleological structures concerned with the ways in which the future of the EU is defined and justified. The ESPON research communities are thus characterized by a superficial common understanding of the nature and ends of European integration.

Activity spaces are meaningful sites of interaction (cf, Schatzki, 2002). As an example of significance, the EU officials as well as academics connected to the ESPON often use the term 'ESPON space' when referring to the objects of their actions. This is a peculiar term which is increasingly used not only in the 
ESPON research projects but also even in academic publications, demonstrating, yet again, the ways in which academic labor is brought into the activity spaces of the EU territory.

Taken together, the ESPON not only produces representations of the EU territory but also seeks to inform state agencies, local stakeholders and even individual actors on best practice guidelines - and, at least potentially, channels action accordingly. As an activity space, the ESPON contributes to the formation of a scientifically informed policymaking and related audit culture of the EU territory, to the production of the EU territory (cf, Bachmann, 2015a), and to the dissemination of particular ways of seeing that political space.

\section{The European knowledge-based economy and the structuring of the ESPON research projects}

ESPON activities are carried out mainly through research projects, which are categorized under three priorities. Applied research projects comprise thematically defined research, cross-thematic research and policy impact studies which seek to provide European-wide information and evidence on territorial potentials and challenges. The targeted analyses are demand-led projects which provide tailor-made information on particular contextual policy issues and challenges. The scientific platform and tools form the core element of ESPON by providing and maintaining a European-wide database under which territorial data, indicators, typologies, methodologies, maps and other outputs of ESPON projects are stored. The touchstone for the ESPON programme and the research projects it funds has always been that the data and knowledge provided on European territory, population and their dynamics must be comparable, easily transferable and harmonized (e.g. ESPON, 2004, page 126; ESPON, 2007, page 43; ESPON, 2014b, page 9).

In this section, we examine the ESPON research projects in order to discern the ways in which they are engaged in "coding" (Painter, 2010) the EU territory as a knowledge-based economy. In practice, we have analysed the contents of the interim reports, inception reports, final reports and scientific reports produced in 
46 applied research projects and targeted analyses in the course of the ESPON 2013 programme. In our analysis, we undertook several layered readings on the thematical framings, background assumptions, research choices, study designs, concluding remarks as well as other statements of the research projects. These readings disclosed a pattern that characterizes the ESPON as a collective activity space. This pattern has to do with the three observed relations of the analysed projects with respect to the broader teleological structure of the European knowledge-based economy. We refer to these three dimensions as political framings, conceptual orderings and consolidations in the form of policy guidelines; these seem to be crucial for the very existence of the ESPON as an activity space.

Political framing of the activity space: Explicit commitment to the European knowledge-based economy through the political agendas and discourses

Painter (2010, page 1104) argues that the possibility of conceiving of territory as a policy object requires its coding as a delimited and coherent space. The analysed projects covered a wide range of different themes varying from energy and climate change to landscape and land-use issues, and from the challenges of globalization and accessibility to the opportunities of rural and geographically specific areas. Despite the great thematic variety, the political framing of Europe as a knowledge-based economy was almost invariably written into the project reports. This coherence in framing the EU or Europe is not surprising because it was explicitly articulated that the ESPON should "provide new territorial evidence from a European perspective in support of differentiated regional contributions to the Europe 2020 Strategy" (ESPON, 2013b, page 3). Some projects, such as KIT (ESPON, 2012a) and AMCER (ESPON, 2012b) were explicit about their commitment to the advancement of the European knowledge economy:

\footnotetext{
"Knowledge has in recent years become a key driver for growth of economic systems, and the access to knowledge is generally considered as a key condition for innovative activities in our modern economy. The project takes this policy context as a starting point to explore the territorial dimension of the innovation and knowledge economy.... This project will take into account the current state, patterns and potentials of regions with respect to the knowledge and innovation economy and identify new development opportunities through innovation for Europe and its territories" (ESPON, 2012a).
} 
It is noteworthy that the Lisbon strategy, Europe 2020 and the Territorial Agenda were the most referred-to political strategies. This is not surprising, for the renewed Lisbon Agenda and sustainable development are mentioned as key community priorities and the ESPON programmes are explicitly committed to the achievement of these objectives (e.g. ESPON, 2007, pages 6-8, page 26). In the majority of the project reports, these political agendas were used to outline the political context of the studied phenomena while in some projects, such as SIESTA (ESPON 2012c) and ET2050 (ESPON 2013a), were explicitly devoted to providing knowledge and means for achieving the goals set in these political agendas of the EU.

There were a few projects that were not explicitly engaged with the idea of Europe as a knowledge-based economy (e.g. ESPON, 2012d). However, these particular projects interestingly disclosed another dimension of the political framing of the ESPON as an activity space: the blatant emphasis on the crucial role of scientific knowledge production and expertise in 'good' policymaking. Since the launch of the first programme in 2002, the leitmotif of the ESPON programmes has been the need for rigorous scientific information for the purposes of European spatial development policies-(e.g. ESPON, 2004, page 9). This ambition is driven by an underlying idea of Europe as an organism or functional ensemble which is malfunctioning due to inefficient use of its diverse territorial potential and capacities (e.g. EU ministers..., 2011). One interviewed official emphasized that regional development is a complex phenomenon and compared his work to doctors who explore the symptoms of patients, set and test different hypotheses and use different tools to diagnose and cure the diseases:

\footnotetext{
"Regional policy ... is like medical science. If I go to my doctor and say 'I have a sore throat', my doctor may suspect as much - he'll start with a working hypothesis, is it cold or flu? But if it persists for a couple of weeks or a month or two, he may have to consider another hypothesis, he may test other things. Sometimes the problems go away without anybody ever knowing what they were. And I think that regional economics is like that ... we don't always know what the secret is, for something which works in one region won't necessarily work in another. Sometimes regions get better and converge without us ever knowing exactly why they did it.... It [the work of regional policymakers] is the complication of everything...” (EU official, 22 May 2015)
} 
The purpose of the scientific knowledge production in ESPON is to help policymakers to make sense of these complications, to diagnose the inefficiencies of the EU territory and to discover the underused potentials by providing novel, applicable, user-friendly and timely information about the spatial dynamics and opportunities of Europe and its constituents (e.g. ESPON, 2007, page 8).

The rationale of the ESPON is thus founded upon the practices of producing, acquiring, sharing and using knowledge to enhance the performance of socio-spatial entities, such as regional institutions, policies and economies. As such, the ESPON per se is an illustrative embodiment of the wider perception of the centrality of knowledge - and the consequential ability to monitor policy performances - that prevails within the EU. The interviewed EU policy officials, for instance, highlighted the increased importance of the calculative techniques and various other kinds of knowledge production practices in their work. One of the interviewed EU policy analysts working with the performance framework of the European Structural and Investment Funds ${ }^{4}$, who illustratively called himself a "guardian", noted that his responsibility is to "try to bring evidence as much as possible" (21 May 2015) in support of his work in monitoring and evaluating policy performances and achievements. Accordingly, knowledge is not only an economic asset but also a meaningful policy resource in the contemporary re-making of European societies which frames the activities of the EU policy community in general and the ESPON programme in particular.

Ordering of the activity space: Towards measuring and mapping 'knowledge' in economy

The political framings of the ESPON programme lay a foundation for conceptual and methodological work within the ESPON activity space. At the level of political framings of the interrogated ESPON projects, the EU or Europe emerges as a coherent territorial entity with shared goals. Beyond this coherence, the ESPON projects articulated another dimension which was more fragmented and spatially selective. In these articulations, Europe was conceptualized through a set of particular theoretical ideas and concepts on the ways in which economy, knowledge and space come together. In a number of projects the entire theoretical 
research frame was built upon the idea of the centrality of knowledge as a factor of production and the region's economic competitiveness.

Even if some of the project reports were not overly specific about their theoretical premises, the majority of the projects straightforwardly appropriated the ideas of agglomeration economies and urbanization economies in which technological spill-overs, pooling of skilled labour and transfer of knowledge among actors in close proximity play crucial explanatory roles. Examination of the scientific background reports (e.g. ESPON, 2009; 2010a) brought out that the research literature used was strongly weighted towards particular segments of economic geography and spatial economics literature that emphasize innovation systems, learning regions and polycentricity as central factors of economic success for political units such as regions or cities (cf, Vandermotten et al, 2008).

The analyses of the research materials highlighted that the adoption of particular concepts of economic geography is essential for the production of the EU territory. In the examined ESPON projects it provides a founding lexicon for conceptualizing the European knowledge-based economy (e.g. ESPON, 2010b). Moreover, this economic geography lexicon is significant in that it allows the creation of spatial indices of the knowledge-economy. A majority of the projects had selected rather conventional and established knowledge-economy-related indicators to describe regional economic conditions. Indicators such as the index of creative professions, number of patent applications, density of research networks, R\&D investments, scientific publications, high skilled labour, education and so on were used to describe regional skills, innovativeness and capacities which, ultimately, would indicate the advancement and (un-)success of regions in capitalist globalization (e.g. ESPON, 2013c).

In most of the analysed project reports, the conditions for knowledge-based economies and the associated opportunities and challenges of the European knowledge economy were ordered through a particular shared and ultimately dualistic understanding of space. In an inception report of an applied research project, for instance, it was stated that 
"Within this policy context [the Lisbon strategy], the main question in the policy domains covered by ESPON is obviously the role and fate of regions and regional economies in Europe's path to a globalised economy. This means, on the one hand, the impact of increased openness, increased trade and more global location decisions on the economic development of individual regions; and, on the other hand, the role of regions in the overall position of Europe in the global economy." (ESPON, 2010c, page 3)

Accordingly, the global economic struggle between Europe and its competitors takes place between regions and localities - especially between cities and larger urban agglomerations (e.g. ESPON, 2013d). This is only one of the nodal ways through which the concept of the polycentricity, and the associated idea of the capacity of regions to 'fare' in 'global' circumstances, was built in the ESPON activity space.

The idea of Europe as a functional spatial entity consisting of various interacting and mutually supporting components was confirmed by imagery of networks, corridors and polycentric patterns of the European research and innovation nodes. In the examined documents, this idea of the 'functional geographies' of the European knowledge economy, however, was not all-embracing but rather selective in terms of which components have a role in the entirety. The composition of the European knowledge economy was exclusively drawn in the sense that it encompassed only particular segments (for instance particular hightech industries and highly-skilled and talented workers) of society as central constituents. The same held true with the spatial representations which emphasized the role of cities and urban agglomerations in strengthening the knowledge-base of the European economy (cf, Dijkstra, 2004). At the same time, however, the knowledge-based economy was considered feasible also for the excluded areas, provided that they were able to engage with it in some ways. The framework for a targeted analysis TeDi project, for example, was

\footnotetext{
"based on an optimistic perspective on centre-periphery relations that does not condemn areas with geographic specificities to dependency but, on the contrary, credits them with the capacity of generating potentially innovative environments." (ESPON, 2010b, page 108)
} 
This statement is illustrative not only of a neoliberal policy talk where 'problems' are considered 'challenges' and 'regional handicaps' as 'regional specificities' but also of an evolutive thinking, peculiar to many of the studied projects, according to which the excluded regions could better their positions in the global knowledge economy simply by developing their capacities to produce, process and adapt knowledge and innovations (e.g. 6ESPON, 2012e). Yet, as one of the EU officials noted, "not every region has to be a Silicon Valley" but regions could be involved in the knowledge-based economy in varying degrees based on their capacities as "we do have the overarching European objectives and somehow we'd like to see the linkages (EU official, 22 May 2015).”

Overall, the similarities between the research designs, theoretical premises and frameworks as well as the several cross-references among the analysed ESPON project reports indicate that the ESPON projects evince a particular kind of shared understanding of the 'proper' ways of knowing and conducting research. This shared epistemological and methodological foundation, which lies upon the teleological structure of the 'European knowledge-based economy', is central in ordering the knowledge production practices within the ESPON activity space.

Consolidating the teleological structure through policy guidelines

The previous political framings and conceptual orderings disclose shared understandings, norms and teleological ends of the ESPON activity space. The existence of the 'European' and even 'global' knowledge-based economy was in many reports considered unreflectively and self-evidently as a current state of affairs or as a reality to be lived with without alternative options. The knowledge-based economy thus appeared almost as a disciplinary form of government. This was clearly spelled out, for instance, in various scenario constructions in which possible regional development paths were conceived as if they were fundamentally determined by advancements and shifts in the 'global knowledge-based economy'. In a project which studied the impacts of high energy prices on the competitiveness and cohesion of European 
regions and cities, the consequences of different political responses were strongly connected to success in the knowledge-based economy in every scenario. For example in the 'worst-case scenario' the economic stagnation due to a loss of political will to invest in the energy sector was "mirrored by a lack of investment in R\&D", from which it followed that

\footnotetext{
"European scientists are now moving to China, India and Brazil, where income possibilities are better.... Now, very few companies can afford to invest in R\&D, and public stimulation schemes are few and poorly funded. The outcome has been a pervasive structural economic problem rooted in dependency on costly energy." (ESPON, 2010d, page 58)
}

Consequently, also the policy conclusions and recommendations offered in the project reports were strongly affected by the dominant idea of the knowledge-based economy forming the preconditions and framework for successful policymaking. The majority of the project reports were premised on the notion that the advancement of the knowledge-based economy sets the limits within which policy actions and choices need to be made. The TIGER project (ESPON, 2012e), for instance, which studied the territorial impacts of globalization, refers to a peculiar "challenge of knowledge" which 'Europe' needs to confront in order to maintain its global position (page 50). Moreover, by quoting the Commission's territorial agenda, the project report states that for particular regions to increase their attractiveness, "there is probably no other way... than 'strengthening research, human capital, [and] the capacity for innovation"” (page 66).

The recommendations of the projects can be divided into hard and soft measures. The former category involved proposals to invest in physical structures and infrastructures such as information and communication technologies as well as in the availability of knowledge-intensive and other services which could attract particular segments of professions and industries. Moreover, the development of research facilities, networks and clusters as well as educational opportunities were similarly stressed as key tools for strengthening regional knowledge-economies in Europe. The latter category, in turn, entailed proposals for improving people's educational and social skills, promoting life-long learning, innovativeness and entrepreneurship, and strengthening innovativeness and entrepreneurial spirit. Overall, the policy 
recommendations and options tended to emphasize the improvement of population and governing capacities to create, manage and capitalize knowledge as well as the strengthening of regional linkages to the resource flows of the global knowledge-economy. This is well in line with the Commission's outlook, which was summed up by a policy official working in one of the DG Regio's country desks as follows:

\footnotetext{
"In terms of the future growth, the most important [targets of investments] are education, innovation and R\&D activities. The Member States would of course like to 'build roads' because it is an easy way to spent lot of money ... but I'd rather invest in people.” (EU official, 20 May 2015)
}

The policy proposals for the spatial reconfiguration of Europe were also guided by the underlying idea of the need to create innovative environments and better opportunities for more efficient capitalization of European knowledge resources. This came out clearly for instance in the policy recommendations that suggested 'place-based' policy approaches and actions such as making better use of regional and local specificities as economic assets, strengthening local research and innovation clusters, developing local knowledge communities and placing emphasis on quality of places (e.g. ESPON, 2012f ).

The strong promotion of 'place-based' approaches and of the better mobilization of local skills and resources present in the project reports derives from the EU's central idea of spatial division of labour, which denotes that territorially specific potential and capital need to be better utilized for the good of the totality (e.g. Barca, 2009). The policy recommendations made in the project reports resonate quite explicitly with the idea of 'smart specialization', an EU territorial policy term which means focusing on 'inherent territorial strengths' ostensibly to better targeting of development resources and, ultimately, to a more efficient harnessing of Europe's human and material assets (cf, EC, 2010b).

\section{Conclusions}

In this article, we have argued that the EU territory can be meaningfully conceptualized as an effect of socio-technical practices. While there are numerous different bundles of practices which contribute to the 
constitution of the EU territory as a political object, in this article we have focused on the particular knowledge production practices involved in a set of research activities conducted within the ESPON research programme.

In general, the bundles of practices open up what can be called the activity spaces of the EU territory. These spaces are sites of interaction which gather various actors together to work, debate and share ideas in the name of the EU territory. In this article, we have scrutinized the ESPON as a distinctive activity space of the EU territory which ties together research institutes, policy organizations and think tanks, individual debaters and scholars, as well as their techniques of knowledge production, expertise on spatial policymaking, and research.

We have also highlighted that the EU territory is always situated within particular, historically contingent, teleological structures. These teleological structures regulate or affect the practices within the activity spaces by delimiting the acceptable, enjoined or prescribed ends and activities that the actors should or may pursue and perform (cf, Schatzki, 2002, page 80). In our analysis of the contemporary making of the EU territory in the ESPON programme, we have demonstrated the ways in which the 'European knowledge-based economy' functions as a teleological structure to condition the production of the EU territory as a political object.

The 'European knowledge-based economy' has worked as a teleological structure of the ESPON activity space in three different ways: First, it has framed the ESPON programme politically by emphasizing the centrality of knowledge both as a political asset for conducting policies more efficiently and as an economic asset for strengthening the position of Europe in the face of 'global competition'. Second, it has contributed to the ordering of the 'ways of knowing' and conducting research activities within the ESPON. Third, it has also delimited the range of projects and tasks that should be carried out in Europe in order to reach particular economic goals, by affecting the policy recommendations and guidelines given in the ESPON research projects. 
For the ESPON activity space the 'European knowledge-based economy' constitutes a self-enforcing system. By politically framing the goals of the ESPON programme, it affects the ways in which the research activities of ESPON projects are carried out. This leads to the setting of policy recommendations and guidelines geared towards a pre-ordained economic goal. Finally, these recommendations further consolidate the status of the 'knowledge-based economy' as a political framework under which the ESPON programme functions.

As a final note, we want to highlight that we have examined only a small slice of the 'totality' of the practice-arrangement bundles which constitute the EU territory (cf, Schatzki 2015, 5). Besides the ESPON, there are various other policy programmes which contribute to the production of the EU territory as a political object. These EU-orchestrated policy programmes form activity spaces which operate rather independently from each other, with respective budgets, timetables, and financial resources. However, their practices become interrelated through the shared teleological structure of the 'European knowledge-based economy'. Examples of programmes interconnected with the ESPON, and each other, are the Intercultural Cities, Urban Audit and Smart Cities projects, which all lie at the core of the EU's strategies of the knowledge-based economy. However, the connections between the practices of EU programmes and the associated (im-)material arrangements have not been thoroughly scrutinized in political geographical studies of the EU. Studying the role of shared or common understandings and forms of knowledge in organizing the policy practices within these different programmes might provide interesting insights into the ways in which the EU territory is constituted as a socio-technical entity.

\section{References}

Bachmann V, 2015a, "Global Europa, ESPON and the EU's Regulated Spaces of Interaction” Journal of European Integration 37 685-703, DOI: 10.1080/07036337.2015.1050012. 
Bachmann, V 2015b "Spaces of Interaction: Enactments of Sociospatial Relations and an Emerging EU

Diplomacy in Kenya” Territory, Politics, Governance, DOI:10.1080/21622671.2015.1005124

Barca F, 2009, “An agenda for a reformed cohesion policy: A place-based approach to meeting European Union challenges and expectations”, Independent Report prepared at the request of Danuta Hübner,

Commissioner for Regional Policy

Barry A, 1993, "The European Community and European government: Harmonization, mobility and space" Economy and Society 22 314-326

Bialasiewicz L, Elden S, Painter J, 2005, “The Constitution of EU Territory” Comparative European Politics 3 333-363

Bialasiewicz L, Giaccaria P, Jones A, Minca C, 2013, “Re-scaling 'EU'rope: EU Macroregional Fantasies in the Mediterranean” European Urban and Regional Studies 20 59-76

Brighenti A, 2014, "Mobilizing territories, territorializing mobilities" Sociologica 1 1-25

Clark J, Jones A, 2008, "The spatialities of Europeanisation: Territory, government and power in 'EUrope"” Transactions of the Institute of British Geographers (New Series) 33 300-318

CSD, Committee on Spatial Development, 1999, "European Spatial Development Perspective"

Luxembourg, Office for the Official Publications of the European Community

Davoudi S, 2006, "Evidence-based planning: rhetoric and reality" disP - The Planning Review 165 14-24

DeLanda M, 2006, A New Philosophy of Society: Assemblage Theory and Social Complexity (Continuum, London)

Dijkstra L, 2004, "European cities in a dynamic, knowledge-based economy”, in Kaupunkiseutujen kasvun aika Eds J Antikainen, T Pyöriä (Sisäasiainministeriö, Helsinki) pp 16-19

Dühr S, Colomb C, Nadin V, 2010, European Spatial Planning and Territorial Cooperation (Routledge, London)

Elden S, 2010, “Land, terrain, territory” Progress in Human Geography 34 799-817

ESPON, European Observation Network, Territorial Development and Cohesion, Luxembourg, 2004, “The ESPON 2006 Programme. Programme on the spatial development of an enlarging European Union", Ministère de l'Intérieur et de l'Amenagement du Territoire, Luxembourg, 
http://www.espon.eu/main/Menu_Programme/Menu_ESPON2006Programme/communityinitiativeprogram me.html

2007, "ESPON 2013 PROGRAMME: European observation network on territorial development and cohesion”, Ministère de l'Intérieur et de l'Amenagement du Territoire, Luxembourg, http://www.espon.eu/main/Menu_Programme/Menu_ESPON2013Programme/ 2009, “SURE - SUccess for convergence Regions’ Economies”, Inception report, ESPON \& LUPT Research Centre, Naples, http://www.espon.eu/main/Menu_Projects/Menu_TargetedAnalyses/SURE.html 2010a, "CAEE - The case for agglomeration economies in Europe", Final Report, ESPON \& University of Manchester, Manchester, http://www.espon.eu/main/Menu_Projects/Menu_TargetedAnalyses/CAEE.html 2010b, “TEDI - Territorial Diversity”, Final Report, ESPON \& Nordregio, Stockholm, http://www.espon.eu/main/Menu_Projects/Menu_TargetedAnalyses/espontedi.html 2010c, “Territorial Impact of globalization on European Regions", Inception report, ESPON \& Free University of Brussels, Brussels, http://www.espon.eu/main/Menu_Projects/Menu_AppliedResearch/tiger.html 2010d, "ReRisk - Regions at Risk of Energy Poverty”, Final Report, ESPON \& Innobasque, Zamudio, http://www.espon.eu/main/Menu_Projects/Menu_AppliedResearch/rerisk.html 2012a, “KIT - Knowledge, Innovation, Territory”, Final Report, ESPON \& Politecnico di Milano, Milan, http://www.espon.eu/main/Menu_Projects/Menu_AppliedResearch/kit.html 2012b, "AMCER - Advanced monitoring and coordination of EU R\&D policies at regional level”, Final Report”, ESPON \& Innova Europe, Luxembourg, http://www.espon.eu/main/Menu_Projects/Menu_TargetedAnalyses/amcer.html 2012c, “SIESTA - Spatial Indicators for a ‘Europe 2020 Strategy’ Territorial Analysis”, (Draft) Final Report, version 10/08/2012, ESPON \& Universidade de Santiago de Compostela, Santiago de Compostela, http://www.espon.eu/main/Menu_Projects/Menu_AppliedResearch/siesta.html 
2012d, "TERCO - European Territorial Co-operation as a Factor of Growth, Jobs and Quality of Life", Final Report, ESPON \& EUROREG, Warsaw, http://www.espon.eu/main/Menu_Projects/Menu_AppliedResearch/terco.html 2012e, “TIGER - Territorial Impact of Globalization for Europe and its Regions”, Final Report, ESPON \& Université Libre de Bruxelles, Brussels, http://www.espon.eu/main/Menu_Projects/Menu_AppliedResearch/tiger.html 2012f, “ATTREG - The Attractiveness of European regions and cities for residents and visitors”, Final report, ESPON \& University Rovira i Virgili, Tarragona, http://www.espon.eu/main/Menu_Projects/Menu_AppliedResearch/attreg.html 2013a, "ET2050 - Territorial Scenarios and Visions for Europe”, Second Interim Report, ESPON \& MCRIT Ltd, Barcelona, http://www.espon.eu/main/Menu_Projects/Menu_AppliedResearch/ET2050.html 2013b, “Territorial Dimensions of the Europe 2020 Strategy”, ESPON 2013 Programme Coordination Unit, Luxembourg 2013c, "GROSEE - Growth Poles in South East Europe", Draft Final Report, ESPON \& University of Bucharest, Bucharest, http://www.espon.eu/main/Menu_Projects/Menu_TargetedAnalyses/grosee.html 2013d, "TOWN - Small and medium sized towns in their functional territorial context", Interim Report, ESPON \& KU Leuven, Leuven, http://www.espon.eu/main/Menu_Projects/Menu_AppliedResearch/town.html 2014a, "Territories finding a New Momentum: Evidence for Policy Development, Growth and Investment. Third ESPON Synthesis Report”, ESPON, Luxembourg. 2014b, “ESPON 2020 Cooperation Programme”, ESPON, Luxembourg, http://www.espon.eu/export/sites/default/Documents/Programme/ESPON2020/ESPON2020Consultation/ CP_PUBLIC_CONSULTATION_ESPON_2020-V5-4-3-2014.pdf

EU Ministers responsible for Urban and Spatial Development, 2007, "Territorial Agenda of the European Union: Towards a More Competitive and Sustainable Europe of Diverse Regions", agreed on the occasion of the Informal Ministerial Meeting on Urban Development and Territorial Cohesion in Leipzig on $24-25$ May 2007 
EU Ministers responsible for Spatial Planning and Territorial Development, 2011, "Territorial agenda of the European Union 2020: Towards an inclusive, smart and sustainable Europe of diverse regions”, http://www.eu2011.hu/files/bveu/documents/TA2020.pdf

EC, European Commission, 2010a, Investing in Europe's future. Fifth report on economic, social and territorial cohesion (Publications Office of the European Union, Luxembourg)

2010b, Communication from the Commission: Europe 2020 - A strategy for smart, sustainable and inclusive growth. COM(2010) 2020, European Commission, Brussels

2014, “Guidance fiche performance framework review and reserve in 2014-2020”, http://ec.europa.eu/regional_policy/sources/docgener/evaluation/pdf/guidance_performance_framework.p df

European Communities, 2006, "Creating an Innovative Europe”, Report of the Independent Expert Group on R\&D and Innovation chaired by Mr. Esko Aho (Office for Official Publications of the European Communities, Luxembourg)

European Council, 2000, Presidency Conclusions of the Lisbon European Council, 23 and 24 March (European Council, Lisbon)

Faludi A, 2010, Cohesion, Coherence, Cooperation: European Spatial Planning Coming of Age?

(Routledge, London)

Federal Office for Building and Regional Planning, 2001, Study Programme on European Spatial Planning (Federal Office for Building and Regional Planning, Bonn)

Godin B, 2006, “The Knowledge-Based Economy: Conceptual Framework or Buzzword?” Journal of Technology Transfer 31 17-30

Jensen OB, Richardson T, 2004, Making European Space: Mobility, Power and Territorial Identity (Routledge, London)

Jones HC, 2005, "Lifelong Learning in the European Union: whither the Lisbon Strategy?" European Journal of Education 40 247-260 
Krzyżanowski M, Wodak R, 2011, "Political strategies and language policies: the European Union Lisbon strategy and its implications for the EU's language and multilingualism policy" Language Policy 10115 136

Kuus M, 2014, Geopolitics and Expertise: Knowledge and Authority in European Diplomacy (WileyBlackwell)

Lundvall B $\AA$, ed, 1992, National Systems of Innovation: Towards a Theory of Innovation and Interactive Learning (Pinter, London)

Miller P, Rose N, 2008, Governing the Present: Administering Economic, Social and Personal Life (Polity Press; Cambridge)

Luukkonen J, 2011, “The Europeanization of regional development: local strategies and European spatial visions in northern Finland" Geografiska Annaler: Series B, Human Geography 93 253-270.

Mitchell T, 2002, Rule of Experts. Egypt, Techno-Politics, Modernity (University of California Press, Los Angeles)

Moisio S, 2011, “Geographies of Europeanization: The EU's spatial planning as a politics of scale”, in Europe in the World: EU Geopolitics and the Transformation of European Space Ed L Bialasiewicz (Ashgate Publishing Limited, Aldershot) pp 19-39

Moisio S, 2015, "Geopolitics/critical geopolitics", in The Wiley-Blackwell Companion to Political Geography Eds J Agnew, V Mamadouh, A Secor, J Sharp (Wiley Blackwell, Oxford) pp 220-234 Moisio S, Bachmann V, Bialasiewicz L, dell'Agnese E, Dittmer J, Mamadouh V, 2013, "Mapping the political geographies of Europeanization: National discourses, external perceptions and the question of popular culture" Progress in Human Geography 37 737-761

Moisio S, Luukkonen J, 2015, "European spatial planning as governmentality: an inquiry into rationalities, techniques, and manifestations" Environment and Planning C: Government and Policy 33 828-845

OECD, Organisation for Economic Cooperation and Development, 1996, The knowledge-based economy (OECD, Paris)

Painter J, 2010, “Rethinking territory” Antipode 42 1090-1118 
Schatzki T R, 1996, Social Practices: A Wittgensteinian Approach to Human Activity and the Social

(Cambridge University Press, Cambridge)

Schatzki T R, 2002, The site of the social: a philosophical account of the constitution of social life and change (The Pennsylvania State University Press, Pennsylvania)

Schatzki T R, 2010, The Timespace of Human Activity: On Performance, Society, and History as

Indeterminate Teleological Events (Lexington Books, Lanham, Md)

Schatzki T R, 2015, "Spaces of Practices and of Large Social Phenomena”,

http://www.espacestemps.net/en/articles/spaces-of-practices-and-of-large-social-phenomena/

Sidaway J, 2006, "On the nature of the beast: re-charting political geographies of the European Union"

Geografiska Annaler B 88 1-14

Vandermotten C, Halbert L, Roelandts M, Cornut P, 2008, "European Planning and the Polycentric

Consensus: Wishful Thinking?” Regional Studies 42 1205-1217

Walters W, Haahr J H, 2005, Governing Europe: discourse, governmentality and European integration

(Routledge, Abingdon)

\footnotetext{
${ }^{1}$ The temporal component of the activity timespace is not dealt with in this article, thus we use the term "activity space" hereafter. The temporal component refers to the past occurrences and future anticipations which govern and regulate the present activities (of a particular practice) (see Schatzki 2010, 47-51 for a more detailed explanation).

2 The so-called Aho Group Report, for instance, notes that 'a paradigm change is needed in which European values are preserved but in a new social structure.' The report states that 'the paradigm shift cannot be confined to the narrow domain of R\&D and innovation policy' and demands a new type of cosmopolitan entrepreneurial citizen with willingness for risk-taking (European Communities 2006).

${ }^{3}$ The term 'infography' was introduced in the Study Programme on European Spatial Planning (SPESP), which was carried out during 1998-2000 as a test phase of the first ESPON programme. Infography was defined as a visualizing method to complement conventional cartographic methods which 'aimed at exploring alternative new methods of visualizing spatial policies which could make progress towards a better understanding of the overall communication problem' (Federal Office for Building and Regional Planning 2001, 128).

${ }^{4}$ The performance framework is a table which defines the milestones and targets for each of the priorities of the operational programmes funded from the EU's structural and investment funds. It consists of selected financial, output and result indicators as well as key implementation steps for the priorities which are used to evaluate the performance and resultativeness of the programmes (European Commission 2014).
} 